\title{
Host use patterns and demography in a guild of tropical sponge-dwelling shrimps
}

\author{
J. Emmett Duffy* \\ Department of Invertebrate Zoology, National Museum of Natural History, Smithsonian Institution, Washington, DC 20560, USA
}

\begin{abstract}
Demographic consequences of the commensal lifestyle for shrimps Synalpheus spp. were assessed by sampling sponges and coral rubble on reefs in Caribbean Panama. Eight of 22 species were found solely or primarily within the internal canals of sponges. Among these sponge-dwellers, host specificity ranged from generalism (occurrence in $\geq 4$ host species) to specialization on a single host species, and sponges used in the field were also preferred in laboratory choice assays. Living in sponges had important consequences for shrimp populations. Parasitism by epicaridean isopods averaged 6 times higher in obligate sponge-dwellers (17\%) than in free-living species $(2.5 \%)$. Sponge species differed in the mean size and size range of habitable spaces they provide, number of potentially competing Synalpheus species they support, and vulnerability of associated shrimps to parasitism. Similarly, conspecific shrimp populations occupying different hosts differed demographically. Specifically, populations of Synalpheus brooksi in the sponge Spheciospongia vesparium were significantly less dense, less parasitized, had larger body sizes, and tended toward higher proportions of mature females than conspecifics in the co-occuring sponge Agelas clathrodes. High host specificity, regional variation in host use, and demographic and genetic differentiation among conspecific shrimps in different host species suggest that the commensal lifestyle has pervasive, and potentially evolutionarily important, consequences for the population biology of this diverse group of shrimps.
\end{abstract}

\section{INTRODUCTION}

Snapping shrimps in the genus Synalpheus are among the most diverse decapod crustaceans in shallow tropical waters, with over 100 species worldwide and 30 presently recognized from the Caribbean region (Banner \& Banner 1975, Dardeau 1984, Chace 1989). Alpheids generally, and Synalpheus in particular, are also among the most abundant mobile macrofauna in coral reef environments (Reed et al. 1982, Snelgrove \& Lewis 1989 , Moran \& Reaka-Kudla 1991) and the crackling sound produced by large numbers of these shrimps snapping their chelae is familar to scuba divers throughout the tropics. While many snapping shrimps are 'free-living' inhabitants of dead coral, loose rubble, or sediments, the family also includes a large number of species that associate with other invertebrates, including sponges, corals, sea anemones, sea urchins, and crinoids (Banner \&

- Present address: Department of Zoology and Center for Population Biology, University of California, Davis, Davis, California 95616, USA
Banner 1975, Knowlton 1980, Dardeau 1984, Nakashima 1987). Many alpheids live in mated pairs as adults, and some vigorously exclude conspecifics from occupied hosts (Knowlton 1980, Nakashima 1987).

Intimate associations such as those between shrimps and sessile invertebrates are widely recognized as a hallmark of tropical marine communities (Kaplan 1982, Levinton 1982); however, the nature of the interactions between species involved in most such associations is not well established. In recognition of this uncertainty, the generic term 'guests' is often used for the small motile animals that associate with sessile 'hosts' (Roughgarden 1975, Vermeij 1983). This terminology entails no assumptions about whether the 2 parties are obligate or casual associates, or whether their impact on one another is positive, negative, or neutral. Similarly, for associations that are not clearly parasitic or mutualistic, I use the term commensalism, which connotes that one party (i.e. the guest) benefits from the association while the other (the host) is not significantly affected (Lincoln et al. 1982). Use of these terms is of course provisional, pending evidence of specific effects of one party on another. 
Of the diverse array of sessile organisms that abound on tropical reefs, one of the taxa most frequently used as hosts by commensal animals is the sponges. This is probably due in large part to the abundance of aquiferous canals that permeate the tissues of many sponge species and allow exchange of water with the environment; these canals are exploited as living spaces by a wide variety of small motile invertebrates (Pearse 1932, 1950, Dauer 1973, Westinga \& Hoetjes 1981). In the Caribbean, species of Synalpheus are among the most characteristic and abundant inhabitants of sponges. More specifically, most Synalpheus species that have been reported from sponges in this region belong to the gambarelloides group (Dardeau 1984), a morphologically distinctive suite of species characterized by a brush of setae on the minor first chela (Coutière 1909). The gambarelloides group is found almost exclusively in the tropical West Atlantic, and includes nearly (wo-thirds of the described species of Caribbean Synalpheus (Dardeau 1984), several of which exhibit direct or abbreviated larval development (Dobkin 1965, 1969).

Despite their abundance and diversity, the distribution and habits of the majority of Synalpheus species are poorly known. To ascertain in more detail the habitat specificity of these shrimps and the consequences of their commensal lifestyle, I sampled both sponges and coral rubble from reefs in Caribbean Panama. Here I describe the distribution of Caribbean Synalpheus species between sponges and coral rubble, the population characteristics of the most abundant Synalpheus species occupying 4 common sponge species in this area, and the results of some simple experiments assessing their host specificity.

\section{METHODS}

Study site and sampling. Sampling and experiments were conducted in the vicinity of the Smithsonian Tropical Research Institute's field station in the San Blas Islands on the Caribbean coast of Panama $\left(9^{\circ} 34^{\prime} \mathrm{N}, 78^{\circ} 58^{\prime} \mathrm{W}\right)$. This area comprises numerous small islands and patch reefs supporting an abundant and diverse sponge fauna. More than 20 sponge species ( $\mathrm{n}=1$ to 4 each) were initially sampled in OctoberNovember 1988 in a search for Synalpheus species; most species produced none. Four species were then selected for further examination based on the consistently dense populations of Synalpheus species they supported. These were the following (identified by Belinda Alvarez and Klaus Ruetzler, National Museum of Natural History, Smithsonian Institution).

The loggerhead sponge Spheciospongia vesparium (Order Hadromerida), is a common and conspicuous inhabitant of shallow waters throughout the tropical and subtropical West Atlantic. This dark, pillowshaped sponge grows in seagrass beds, coral reefs, and other nearshore habitats at depths as shallow as $1 \mathrm{~m}$, and it frequently approaches $1 \mathrm{~m}$ in diameter (Kaplan 1982). The commensal fauna inhabiting S. vesparium has been extensively sampled (Pearse 1932, 1950, Westinga \& Hoetjes 1981, Dardeau 1984, Erdman \& Blake 1987). In the San Blas Islands, I sampled this sponge from seagrass beds and reefs $<6 \mathrm{~m}$ deep.

Agelas clathrodes (Order Axinellida) is a bright orange, lobate sponge characteristic of reef slopes (Zea 1987). Although there are no published accounts of the commensal fauna associated with this species, the fauna of its congener $A$. dispar has been studied in both the Gulf of Mexico and the Bahama Islands (Dardeau 1984). I sampled this species from Aguadargana reef in depths of 15 to $20 \mathrm{~m}$, where it commonly reached a size of several liters in volume.

Niphates amorpha (Order Haplosclerida) is a purple to gray, cushion-shaped sponge that encrusts hard substrata (Wiedenmayer 1977, van Soest 1980), reaching the size of a fist or somewhat larger. In the San Blas Islands it occurs from depths of a few meters at least to $20 \mathrm{~m}$. I sampled this species from Aguadargana reef.

Xestospongia rosariensis (Order Haplosclerida) grows as a rigid, chocolate-brown tube or cluster of tubes extending from an encrusting base (Zea \& Rutzler 1983, Zea 1987). In the San Blas Islands these tubes reach ca $50 \mathrm{~cm}$ in length, and occur in water depths of $<2 \mathrm{~m}$ to at least $20 \mathrm{~m}$. I sampled this species from several reefs in the San Blas Islands.

Animals associated with these 4 sponge species were collected by sealing sponge samples in plastic bags underwater, and removing associated animals in the lab. Nine or ten individual sponges of each species were quantitatively sampled (i.e. sponge wet mass was measured). Samples of Niphates amorpha, smaller Xestospongia rosariensis and smaller Agelas clathrodes (< ca $1 \mathrm{l}$ in volume, as estimated by eye) were removed whole from the substratum; Spheciospongia vesparium, larger $A$. clathrodes, and larger $X$. rosariensis were subsampled by cutting a piece of several hundred $\mathrm{ml}$ in volume from the sponge in situ. I attempted to collect samples of similar volume for the 4 species although samples of $N$. amorpha (small sponges, which were collected whole) tended to be smaller than those of other species. Each sponge sample was placed in a tub of water, cut into slices $\leq 1 \mathrm{~cm}$ in thickness, and examined carefully; shrimps were removed alive from sponges and preserved. Since some sponges were subsampled, species of guests that occupied these sponges in only small numbers may have been missed. However, a large number of specimens of these sponges were examined during 
the course of the experiments described below, and support the conclusions from the quantitative samples that I have identified all Synalpheus species that normally occur in these sponges at this site.

In addition to sampling individual sponges I also searched for Synalpheus species in eroded, spongeencrusted coral rubble. In January 1991, a large volume, estimated at a total of 1.5 to $2 \mathrm{~m}^{3}$, of this material (hereafter 'rubble') was removed from reefs at Ulagsukun, Pico Feo, Guigalatupo, Mamitupo, and Porvenir Islands (see Robertson 1987 for map) and returned to the lab in buckets, where it was broken up with a hammer. All specimens of Synalpheus species found were preserved and scored as being either associated or unassociated with (usually unidentified) sponges at the time of discovery. Most shrimps found in association with sponges were still inside the internal canals of the sponges when discovered, suggesting that the disturbance involved in collection did not appreciably change their patterns of distribution; however, because of the uncertainty in these assignments, I designated a species as primarily sponge-dwelling only if $\geq 80 \%$ of specimens collected were found in association with sponges.

Voucher specimens of all Synalpheus species collected are being deposited in the National Museum of Natural History, Smithsonian Institution.

Shrimp demography. All Synalpheus individuals collected were identified to species, sexed, and examined for parasitic isopods which, when present, were identified following Markham (1985). Synalpheus species richness (S) and diversity (Shannon-Wiener $H^{\prime}$ ) were computed for each sponge sample. Mature female Synalpheus species were identified by the presence of healthy, developing eggs and/or by rounded first abdominal pleura. There are no morphological characters that reliably distinguish mature males from juveniles of either sex in Synalpheus species (Dardeau 1984), so these categories were combined here; non-females similar in size to ovigerous females are presumably mature males. Fecundity was not estimated because eggs were sometimes separated from females during sample handling and sorting, and I was thus not confident that they could be counted reliably.

Carapace length $(\mathrm{CL}$, from base of rostrum to posterior margin of carapace) was measured, using an ocular micrometer, as an index of body size in a subset of the individuals from each sponge sample. The subset was selected as follows. First, all unparasitized females (which usually comprised well under half the sample) were measured. If the remaining unparasitized males and juveniles numbered less than 20, all were measured; otherwise the smallest and largest individuals were selected and measured to include the extremes of the size range in the sample, after which individuals were selected randomly (using a random numbers table) from the remaining individuals until a total of 20 unparasitized individuals had been measured. Thus, for each sponge sample, I measured up to 20 individuals, including all females and the entire size range of the sample. With 9 to 10 samples from each sponge species, this amounted to 70 to 195 individuals of each species measured.

Synalpheus brooksi was common in 2 of the sampled sponge species. To assess the impact of differences among host species on shrimp demography, I compared population density, body size, proportion of mature females, and incidence of parasitism between populations of $S$. brooksi from Agelas clathrodes and Spheciospongia vesparium using Mann-Whitney $U$-tests.

Substratum selection. To test shrimp preference for association with sponges versus other common substrata, I offerred shrimps a choice of (1) the sponge species from which they were collected, (2) coral rubble bearing no obvious macroscopic organisms, and (3) seagrass Thalassia testudinum in the laboratory. The latter 2 substrata were used because many of the Synalpheus specimens discussed in Chace's (1972) monograph were reportedly collected from dead coral and seagrass beds; similarly coarse-scaled distribution records characterize many other published reports of Synalpheus species. In preparation for the assay, sponges were cut into pieces approximately $4 \times 4 \times$ $1 \mathrm{~cm}$ in size, then suspended in a mesh bag under the dock where they were allowed to bathe in fresh seawater for at least $30 \mathrm{~min}$ prior to the assays. Treatment of sponges in this way generally ensured that water remained unfouled for the duration of the assay. In each assay ( $\mathrm{n}=7$ to 34 per assay, depending on availability of shrimps and sponges), a piece of host sponge from which all associated animals had been removed, a similar-sized piece of coral rubble, and a shoot of seagrass bearing 3 blades were placed together in a $12.5 \mathrm{~cm}$ diameter bowl filled with about $400 \mathrm{ml}$ of seawater. No other substratum (e.g. sediment) was present. Shrimps of a single species were then introduced, either singly or in a group (depending on the assay), to the bowl and allowed to distribute themselves among the substrata overnight. In the morning, each substratum was quickly removed from the bowl, dipped briefly in freshwater to dislodge the shrimps, and the number of shrimps on each substratum was scored. Assays were performed for $S$. brooksi (from Agelas clathrodes), S. bousfieldi, S. longicarpus, S. pectiniger, and $S$, rathbunae.

I also tested preferences of each shrimp species among the sponges Spheciospongia vesparium, Agelas clathrodes, Niphates amorpha, and in some cases Xestospongia rosariensis. As in the previous assay, 
sponges were cut into pieces, allowed to bathe in seawater beneath the dock, and 1 piece of each sponge species was placed in a bowl. Shrimps were then introduced to replicate bowls ( $\mathrm{n}=9$ to 32 per assay), allowed to distribute themselves overnight, and their positions were recorded in the morning. Assays were run for the same species as in the last assay, plus Synalpheus brooksi from Spheciospongia vesparium.

In initial assays of both types, shrimps were added in conspecific groups (10 to 20 individuals, depending on the assay) to each replicate; later assays used only a single shrimp per replicate. In assays where groups were used, the data were analyzed by counting the number of shrimps associated with each substratum and ranking the substrata within each replicate by this number. Differences among substrata in the frequency of being ranked highest were analyzed with $G$-tests (see Hay et al. 1988). In assays where a single shrimp was added to each repicate, differences among substrata in the number of associated shrimp were determined with a subdivided Chi-square analysis (Zar 1974), using an overall alpha value determined by dividing 0.05 by the total number of comparisons anticipated. In some assays, a few shrimps were not associated with any of the substrata at the end of the experiment. These cases are shown in the figures but are not included in analyses.

Space available in sponges. To characterize the sizes of canal spaces that are available to shrimps, 10 sponges of each species were cut into thin slices, clear plastic sheets were placed over the slices, and the perimeter of each canal was traced on the plastic with a felt-tip pen. For each species, the 5 largest slices from each sponge were traced. Size distributions of spaces were measured by placing a grid of 100 points (regularly spaced at $1 \mathrm{~cm}$ intervals) over the tracing and, for each point that fell over a space, measuring the shortest dimension of that space. Since the canals of these sponges were generally cylindrical and continuous throughout the sponge, the shortest dimension in cross-section appeared to approximate the diameter of the canal regardless of the angle at which the sponge had been sectioned. These measurements were intended to estimate the maximum body width that shrimps using the canal spaces could attain. On each of the 5 slices of an individual sponge, the first 10 points falling over canal spaces were measured, yielding 50 measurements per individual sponge, and 500 measurements per species. For comparisons among sponge species, mean and coefficient of variation (CV) of canal diameter were calculated for each individual sponge (thus $\mathrm{n}=10$ per sponge species) and these values were used as the data in statistical analyses.

Space use by cohabiting shrimps. To assess whether shrimps co-occuring in the same sponge preferentially used spaces of different sizes, laboratory experiments were performed with Synalpheus brooksi and $S$. longicarpus, the 2 species most regularly found sharing the same sponge. In each experiment, shrimps were offered 2 substrata, 1 bearing small holes and the other large holes (see next paragraph). The substrata were pieces $(3 \times 3 \times 1.5 \mathrm{~cm})$ of the sponge Cinachyrella alloclada, which lacks macroscopic canals and can be perforated with artificial canals of the desired diameter.

Canal size preference of Synalpheus brooksi was tested by placing 2 shrimps in a $10 \mathrm{~cm}$ diameter bowl $(\mathrm{n}=28$ ) filled with $150 \mathrm{ml}$ of seawater and containing 1 substratum with two $9 \mathrm{~mm}$ diameter holes and 1 with eight $5 \mathrm{~mm}$ diameter holes. After 12 to $24 \mathrm{~h}$, the position of each shrimp (i.e. which substratum was occupied and whether the shrimp was inside a hole or on the outer surface of the substratum) was recorded.

For Synalpheus longicarpus, a single shrimp was placed in each replicate $(n=35)$, and the substrata bore either three $9 \mathrm{~mm}$ diameter holes or three $7 \mathrm{~mm}$ diameter holes. The smaller holes were $7 \mathrm{~mm}$ in diameter, rather than $5 \mathrm{~mm}$ as in the above experiments, because adult $S$. longicarpus were generally too large to occupy $5 \mathrm{~mm}$ holes but could occupy $7 \mathrm{~mm}$ holes. Position of each shrimp was recorded after 10.5 to $12 \mathrm{~h}$.

\section{RESULTS}

\section{Host and habitat associations of Panamanian Synalpheus}

Nine species of Synalpheus were found in the 4 sponges (Table 1); all of these except the single individual $S$. townsendi belonged to the morphologically distinctive gambarelloides species group (see Dardeau 1984). The rubble collections produced 7 of these same species, together with 13 others (Table 2). Both the number $(S)$ and diversity $\left(H^{\prime}\right)$ of Synalpheus species per sample differed significantly among the 4 sponge species, with Spheciospongia vesparium highest in both measures (Table 3). Different shrimp species dominated in each of the 4 sponges (Table 1).

Using pooled data from sponge (Table 1) and rubble (Table 2) collections, Synalpheus species were classified as sponge-dwellers if $\geq 80 \%$ of the total collected specimens were found in association with sponges. Since volume was not measured for either sponges or rubble, it is not possible to estimate rigorously the relative population densities of shrimps in these 2 habitat types; on the other hand I am confident that I searched a considerably larger total volume of rubble than sponges. This difference in collecting effort should bias against finding a species primarily in sponges, and should thus make my classification of a species as a 
Table 1. Shrimp found in 4 common sponge species in the San Blas Islands, Panama. - Species found only in sponges (i.e. not found in rubble, Table 2)

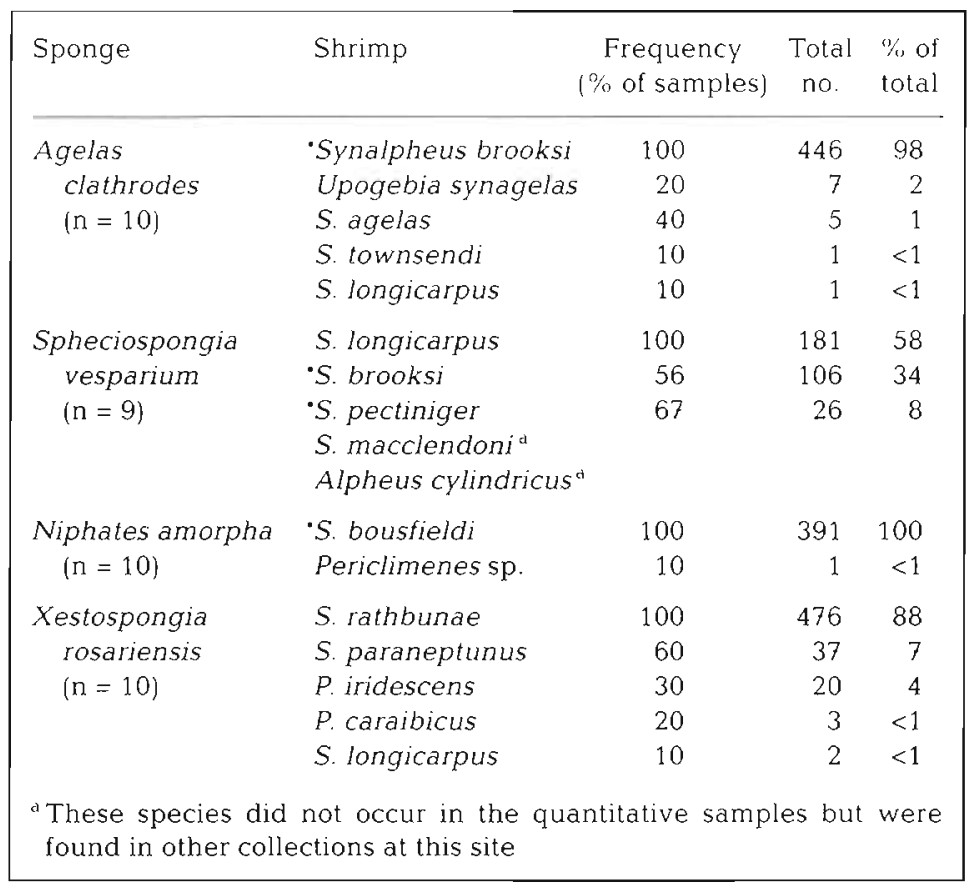

sponge-dweller conservative. For example, only 17 specimens ( $8 \%$ of the total found) of $S$. longicarpus were found in the 1.5 to $2 \mathrm{~m}^{3}$ of rubble examined (Table 2), while 184 specimens $(92 \%)$ were found in the sponge samples (Table 1), which probably amounted to $<0.25 \mathrm{~m}^{3}$. Species represented by a total of $<4$ specimens were judged too rare to categorize accurately in this way. Using these criteria, 8 of 12 species (67\%) in the gambarelloides group, and none of 6 species $(0 \%)$ outside this group were classified as sponge-dwellers (those marked by in Tables $1 \& 2$ ). There is thus a significantly higher frequency of the sponge-dwelling habit among species in the gambarelloides group ( $p=0.011$. Fisher's exact test) than among species outside the group.

\section{Shrimp demography}

For most of the sponge-dwelling Synalpheus species studied, individuals ranging from postlarvae to mature adults were

Table 2. Synalpheus spp. found in coral rubble in the San Blas Islands, Panama. "Species for which $\geq 80 \%$ of total specimens found (Tables 1 \& 2 pooled) were associated with sponges; these are considered primarily sponge-dwelling species. Species for which $<4$ specimens were collected were not classified as to degree of sponge-dwelling

\begin{tabular}{|c|c|c|c|c|}
\hline Shrimp & $\begin{array}{l}\text { No. in } \\
\text { sponges }\end{array}$ & $\begin{array}{l}\text { No. not in } \\
\text { sponges }\end{array}$ & $\begin{array}{l}\text { Total no. } \\
\text { found }\end{array}$ & $\begin{array}{c}\% \text { in } \\
\text { sponges }\end{array}$ \\
\hline \multicolumn{5}{|l|}{ Gambarelloides species } \\
\hline Synalpheus rathbunae & 110 & 7 & 117 & 94 \\
\hline S. paraneptunus ${ }^{\mathrm{a}}$ & 22 & 4 & 26 & 85 \\
\hline S. pandionis & 9 & 14 & 23 & 39 \\
\hline S. longicarpus & 10 & 7 & 17 & 59 \\
\hline S. goodei & 5 & 5 & 10 & 50 \\
\hline 'Synalpheus sp. A (near rathbunae) & 10 & 0 & 10 & 100 \\
\hline S. macclendonj ${ }^{\text {a }}$ & 0 & 9 & 9 & 0 \\
\hline S. bousfieldia & 4 & 1 & 5 & 80 \\
\hline S. anasimus & 1 & 3 & 4 & 25 \\
\hline S. disparodigitus & 0 & 3 & 3 & \\
\hline S. barahonensis & 0 & 2 & 2 & \\
\hline S. agelas ${ }^{\mathrm{a}}$ & 0 & 1 & 1 & \\
\hline \multicolumn{5}{|l|}{ Non-gambarelloides species } \\
\hline Synalpheus brevicarpus & 3 & 15 & 18 & 17 \\
\hline S. dominicensis & 0 & 15 & 15 & 0 \\
\hline S. fritzmuelleri & 2 & 12 & 14 & 14 \\
\hline S. scaphoceris & 0 & 13 & 13 & 0 \\
\hline S. minus & 0 & 14 & 14 & 0 \\
\hline S. townsendi ${ }^{\text {a }}$ & 1 & 11 & 12 & 8 \\
\hline S. hemphilli & 1 & 0 & 1 & \\
\hline Synalpheus sp. D (near brevicarpus) & 0 & 1 & 1 & \\
\hline
\end{tabular}


Table 3. Synalpheus spp. Number (S) and diversity $\left(H^{\prime}\right)$ of shrimp species associated with 4 host sponge species from the San Blas Islands, Panama. Values are expressed as mean $( \pm 1 \mathrm{SE}$ ) per sample. Superscript letters distinguish species that differ significantly $(p<0.05$, Kruskal-Wallis, followed by joint-rank Ryan tests)

\begin{tabular}{|lcc|}
\hline \multirow{2}{*}{ Sponge } & \multicolumn{3}{c|}{ Synalpheus spp. } \\
& Sper sample & $H^{\prime}$ per sample \\
\hline Spheciospongia vesparium $(\mathrm{n}=9)$ & $2.53 \pm 0.17 \mathrm{~A}$ & $0.622 \pm 0.075^{\mathrm{A}}$ \\
Xestospongia rosariensis $(\mathrm{n}=10)$ & $1.70 \pm 0.21^{\mathrm{AB}}$ & $0.215 \pm 0.075^{\mathrm{AB}}$ \\
Agelas clathrodes $(\mathrm{n}=10)$ & $1.60 \pm 0.27 \mathrm{AB}$ & $0.070 \pm 0.032^{\mathrm{B}}$ \\
Niphates amorpha $(\mathrm{n}=10)$ & $1^{\mathrm{B}}$ & $0^{\mathrm{B}}$ \\
\hline
\end{tabular}

Synalpheus bousfieldi was an obligate sponge-dweller. The great majority of individuals was found in Niphates amorpha, in which $S$. bousfieldi was the sole Synalpheus species present and occupied all specimens sampled (Table 1). Whereas the sponge-dwelling Synalpheus species discussed above showed approximately equal sex ratios in adult size classes (Fig. 1), S. bousfieldi exhibited a highly unusual population structure: each sponge, which ranged in wet mass from 12.9 to $30.0 \mathrm{~g}$ and were sampled whole, contained

found in sponges (Fig. 1), supporting the conclusions from sponge and rubble sampling that these species live obligately or primarily in sponges. Nevertheless, density, sex ratio, and host specificity differed among these species, as well as between conspecific populations in different hosts (Table 4).

Synalpheus brooksi was an obligate sponge-dweller, being entirely absent from the rubble (Table 2), and was abundant in 2 of the sampled sponge species (Table 1). Interestingly, there were several demographic differences between $S$. brooksi populations in Spheciospongia vesparium and Agelas clathrodes (Table 4). Population density (normalized to sponge wet mass) of $S$. brooksi was nearly an order of magnitude lower in $S$. vesparium, which it commonly shared with 1 or 2 other Synalpheus species, than in A. clathrodes, in which it was usually the only member of the genus present. $S$. brooksi individuals were also significantly larger, on average, in $S$. vesparium (mean $\mathrm{CL} \pm 1 \mathrm{SE}=3.11 \pm 0.07 \mathrm{~mm}$ ) than in $\mathrm{A}$. clathrodes $(2.83 \pm 0.05, p=0.001$, Mann-Whitney $U$-test $)$, with a similar trend for maximum size per sample $(\mathrm{p}=0.075$, Mann-Whitney $U$-test, see Fig. 1). Finally, there was a trend ( $p=0.076$, Mann-Whitney $U$-test) toward a lower proportion of mature females in the dense populations of $S$. brooksi from A. clathrodes (Table 4).

Synalpheus pectiniger and S. longicarpus were also common in the loggerhead sponge Spheciospongia vesparium in Panama (Table 1), as they are in the Gulf of Mexico (Dardeau 1984, Erdman \& Blake 1987). Synalpheus pectiniger was an obligate sponge-dweller and a specialist on Spheciospongia vesparium, though it was the least abundant of the 3 species commonly found in this sponge (Table 1). Synalpheus longicarpus was a host/habitat generalist. In addition to occupying all specimens of Spheciospongia vesparium sampled (Table 1), Synalpheus longicarpus also occurred in rubble (Table 2), and a very small number of juveniles was found in Agelas clathrodes and Xestospongia rosariensis (Table 1). Adults of both Synalpheus pectiniger and Synalpheus longicarpus tended to occur in mated pairs. a single female bearing developing embryos (with the exception of 1 sponge in which no female was found); all other individuals, up to 60 in a single sponge, were males and juveniles (Fig. 1). In 5 of the 6 samples which contained an undamaged (i.e. measurable) female, this lone temale was the largest individual in the sample.

Synalpheus rathbunae was also an obligate spongedweller, inhabiting all Xestospongia rosariensis sampled (Table 1) as well as 1 or more unidentified encrusting sponge(s) in the rubble (Table 2). The $S$. rathbunae population was strongly biased toward males in adult size classes (Fig. 1, Table 4), as was $S$. bousfieldi. Most $X$. rosariensis sampled contained more than 1 female $S$. rathbunae, however. All females carried developing, apparently healthy embryos, in contrast to other reports of $S$. rathbunae (Coutière 1909, Chace 1972).

Synalpheus paraneptunus was found in relatively small numbers in Xestospongia rosariensis (Table 1) and in rubble, usually in association with unidentified sponges (Table 2).

For all Synalpheus species in this study, virtually all individuals with female morphology (rounded first abdominal pleura) carried healthy eggs or embryos.

\section{Parasitism}

Parasitism by epicaridean isopods was common among sponge-dwelling Synalpheus species, and appeared to be enhanced by the commensal habit: among the 12 gambarelloides species represented by $>4$ specimens, incidence of parasitism was positively related to the percentage of individuals found in association with sponges $(r=0.60, p=0.038$, Fig 2 ). Parasitism was about 6 times higher ( mean $=16.6 \%$ ) in the 4 species found exclusively in sponges than in the 4 species with fewer than $50 \%$ of individuals in sponges (mean $=2.5 \%$ infected, Fig. 2 ). This relation was calculated only for the gambarelloides species since all species outside this group were primarily freeliving (Table 2), and most of the latter supported no 
parasites in my collections. However, the scarcity of parasites in the free-living nongambarelloides species is consistent with the conclusion that sponge-dwelling increases the incidence of parasitism.

Incidence of parasitism also differed between conspecific populations in different sponge species (Table 4). Populations of Synalpheus brooksi from Agelas clathrodes supported a significantly greater number of branchial bopyrid isopods than did conspecifics from Spheciospongia vesparium $(\mathrm{p}=0.003$, Mann-Whitney $U$ test). Conversely, Synalpheus brooksi from Spheciospongia vesparium tended to host more internal (probably entoniscid) parasites $(p=0.058$, Mann-Whitney $U$ test, Table 4). In Synalpheus brooksi populations from both hosts, branchial parasites consisted mainly of the bopyrid Bopyrione synalphei but a few Synsynella choprae were also present in populations from Spheciospongia vesparium.

Synalpheus longicarpus from Spheciospongia vesparium was infected by the branchial bopyrid Synsynella deformans, the abdominal bopyrids Hemiarthrus synalphei and Azygopleon schmitti, and unidentified internal isopods, all at relatively low frequencies (Table 4).

Synalpheus bousfieldi from Niphates amorpha, and Synalpheus rathbunae from Xestospongia rosariensis, were parasitized primarily by unidentified internal isopods (Table 4).

\section{Substratum selection}

As expected, Synalpheus species found with sponges in the field strongly preferred to associate with sponges, relative to sponge-free coral rubble and Thalassia testudinum, in lab assays (Fig. 3). When offered a choice of sponge species, shrimps generally associated preferentially with the sponge from which they were collected in the field (Fig. 4). The exception to the latter pattern was $S$. brooksi, which was found in both Agelas clathrodes and Spheciospongia vesparium in the field. Synalpheus brooksi collected from $A$. clathrodes showed no preference between these 2 sponges in the lab assay; surprisingly, Synalpheus brooksi
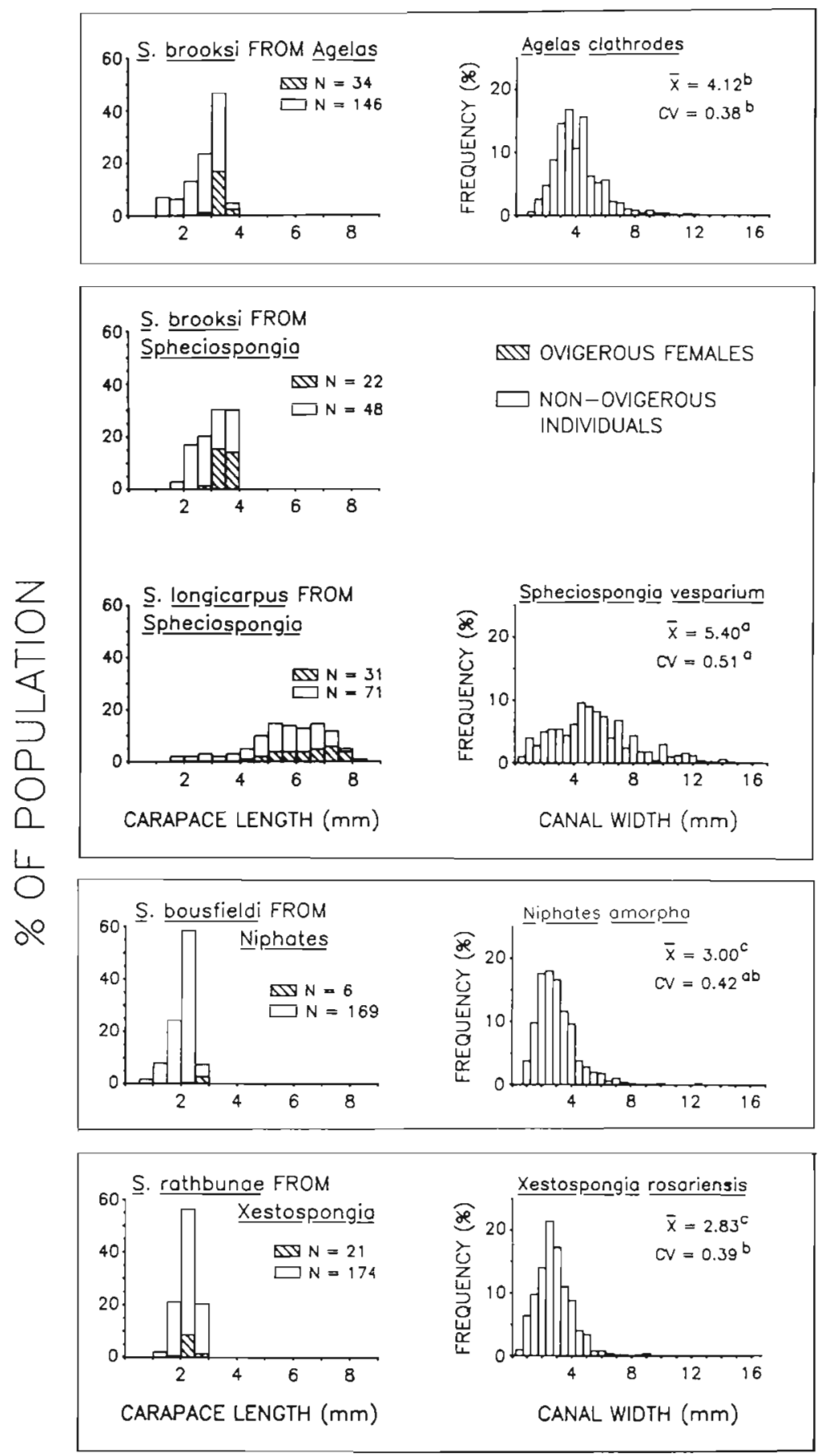

Fig. 1. Synalpheus spp. Size distributions of common sponge-dwelling shrimp (carapace length, at left within each box), and of spaces available within their host sponges (canal width, at right) from the San Blas Islands, Panama. ( Ovigerous female shrimps; $(\square)$ adult males and juveniles of both sexes (which are not morphologically distinguishable). Boxes enclose shrimp species with the sponge in which they occur. Mean and coefficient of variation $(\mathrm{CV})$ of canal widths are given for each of the 4 sponges based on 50 measurements on each of 10 sponges per species $(n=10$ per species); values differing significantly from those of other sponges $(p<0.05$, ANOVA followed by Ryan's $Q$-test) are represented by different superscript letters 
Table 4. Synalpheus spp. Demographic data for sponge-inhabiting shrimp in the San Blas Islands, Panama. Ten sponges of each species were sampled, except for Spheciospongı vesparium $(n=9)$. Listed in parentheses below each species are the no. of samples in which shrimps occurred, and the total no. of shrmps measured, respectively. Populations of $S$. brooksi inhabiting Agelas clathrodes versus Spheciospongia vesparium were compared with Mann-Whitney $U$-tests; significant differences $(\mathrm{p}<0.05)$ between Synalpheus brooksi populations in the 2 host species are indicated by different capitalized letters. Niphates = Niphates amorpha $a_{i}$ Xestospongia = Xestospongia rosariensis

\begin{tabular}{|c|c|c|c|c|c|}
\hline & $\begin{array}{l}\text { S. brooksi } \\
\text { from } \\
\text { Agelas } \\
(10,402)\end{array}$ & $\begin{array}{c}\text { S. brooksi } \\
\text { from } \\
\text { Sphecjospongia } \\
(5,177)\end{array}$ & $\begin{array}{c}\text { S. longicarpus } \\
\text { from } \\
\text { Spheciospongia } \\
(9,279)\end{array}$ & $\begin{array}{l}\text { S. bousfieldi } \\
\text { from } \\
\text { Niphates } \\
(10,363)\end{array}$ & $\begin{array}{l}\text { S. rathbunae } \\
\text { from } \\
\text { Xestospongia } \\
(10,450)\end{array}$ \\
\hline $\begin{array}{l}\text { Population density } \\
\text { (no. } \mathrm{g}^{-1} \text { sponge) }\end{array}$ & $0.279 \pm 0.038^{A}$ & $0.043 \pm 0.006^{\mathrm{B}}$ & $0.067 \pm 0.010$ & $1.83 \pm 0.24$ & $0.322 \pm 0.055$ \\
\hline$\%$ Mature females & $10.0 \pm 0.9$ & $23.1 \pm 6.4$ & $31.6 \pm 5.4$ & $2.9 \pm 0.8^{\circ}$ & $6.4 \pm 1.4$ \\
\hline \multicolumn{6}{|c|}{ Incidence of parasitism (\%) } \\
\hline Branchial & $25.9 \pm 3.1^{A}$ & $6.7 \pm 3.1^{8}$ & $3.3 \pm 1.5$ & $0.2 \pm 0.2$ & 0 \\
\hline Abdominal & 0 & 0 & $1.8 \pm 0.9$ & 0 & 0 \\
\hline Internal & $0.9 \pm 0.6$ & $9.8 \pm 5.4$ & $4.4 \pm 2.0$ & $16.0 \pm 5.1$ & $1.1 \pm 0.5$ \\
\hline Total & $27.2 \pm 3.3$ & $17.7 \pm 4.8$ & $9.6 \pm 3.1$ & $16.1 \pm 5.1$ & $1.1 \pm 0.5$ \\
\hline
\end{tabular}

from Spheciospongia vesparium preferred A. clathrodes over Spheciospongia vesparium. Interpretation of these results is complicated by the fact that the assay of Synalpheus brooksi from A. clathrodes used multiple shrimps per replicate while that for Synalpheus brooksi from Spheciospongia vesparium used only a single individual per replicate. Despite these complications, however, it seems clear that Synalpheus brooksi shows no preference for the host species from which it was collected in either case (Fig. 4).

\section{Space availability and use by shrimps}

The 4 sponge species examined differed in both the mean size of their internal canal spaces and the variance of those sizes (Fig. 1). Although the distributions of canal widths may depart from normality, the actual

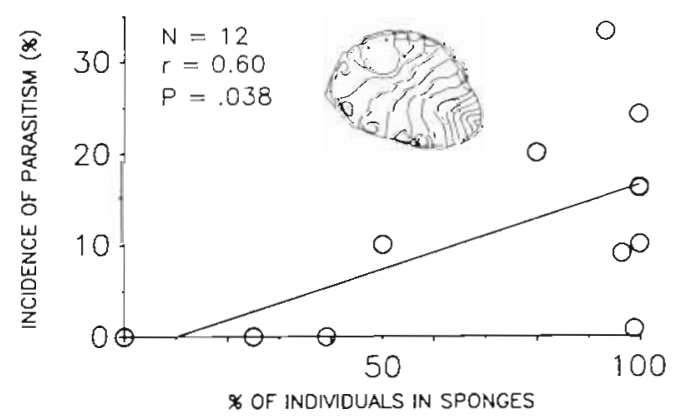

Fig. 2. Synalpheus spp. Relationship between degree of commensalism ( $x$ ) and incidence of parasitism by epicaridean isopods $(y)$ among species in the gambarelloides group. Parasitism increased significantly with the percentage of individuals found in sponges $(y=-1.81+0.183 x, r=0.60, p=0.038)$
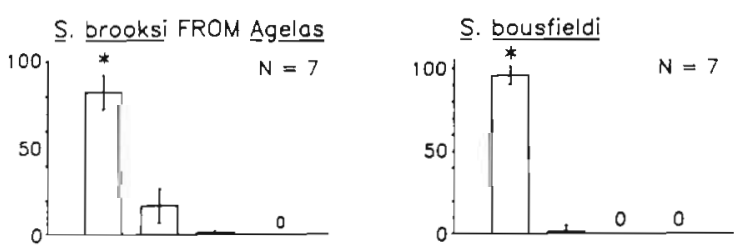

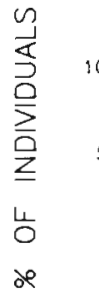
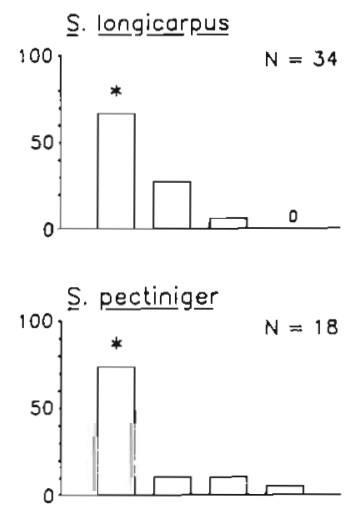

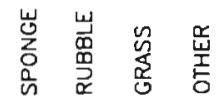

Fig. 3. Synalpheus spp. Substratum selection in the laboratory by shrimp from the San Blas Islands, Panama. Analysis was by Chi-square tests in assays with 1 shrimp replicate ${ }^{-1}$ (where datum plotted is \% of replicates, and thus no error bar), and by contingency table analysis of ranked abundance data in assays with $\geq 1$ shrimp replicate ${ }^{-1}$ (where bar represents mean ( $\pm 1 \mathrm{SE}$ ) \% of shrimps on that substratum across all replicates]. Since cell frequencies were low in categories other than 'sponge', analyses were able to compare only the most preferred substratum with the pooled data for all other substrata; where this difference is significant $(p<0.05)$ the preferred substratum is marked by * (see 'Methods - Substratum selection' for details). Shrimps unassociated with any substratum (OTHER) were not included in statistical analyses 
Fig. 4. Synalpheus spp. Sponge selection in the laboratory by shrimp from the San Blas Islands, Panama. (A) Sponge species from which shrimps were collected. For $S$. brooksi, means in a given assay that are marked by different letters $(a, b, c)$ differ significantly $(\mathrm{p}<0.05)$ by subdivided Chi-square analysis (Zar 1974); other analyses and symbols as in Fig. 3. Note that the 2 assays at right included a choice of 4 sponge species

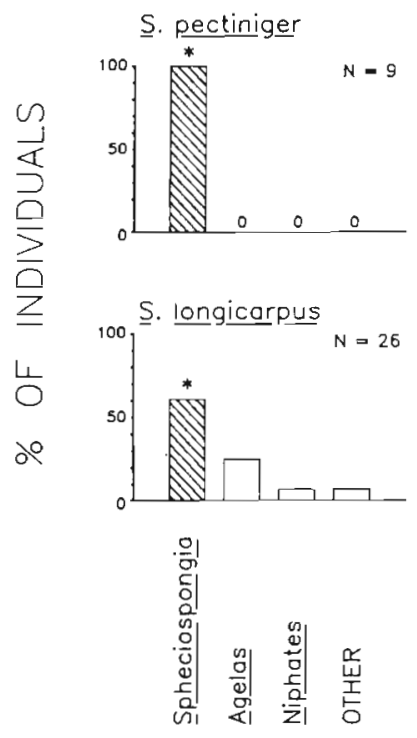

S. brooksi FROM
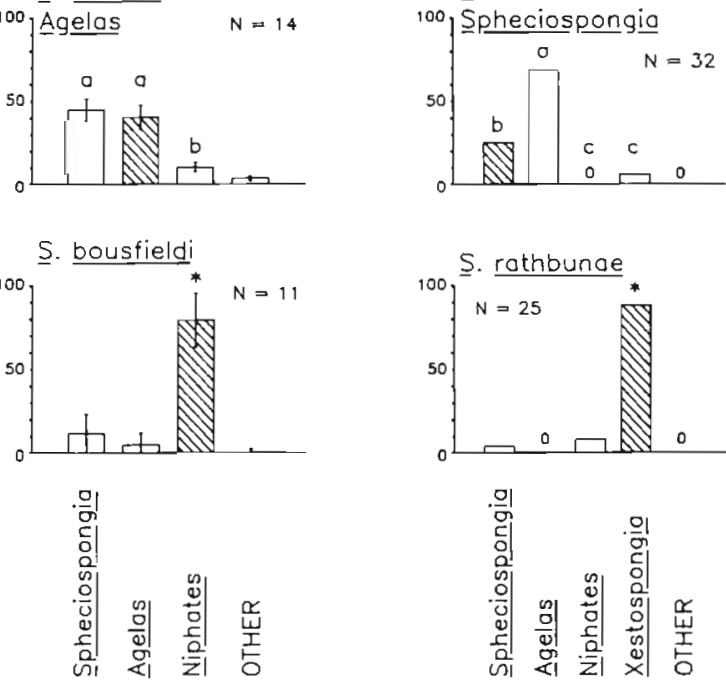

data (mean and CV of canal widths per sample) used in these analyses should approximate normality according to the central limit theorem (Sokal \& Rohlf 1981); thus differences among sponge species in these measures were analyzed with ANOVA followed by Ryan's $Q$ test (Day \& Quinn 1989). Mean canal width was greatest in Spheciospongia, intermediate in Agelas, and smallest in Niphates and Xestospongia which did not differ significantly (Fig. 1). The coefficient of variation in canal width was also greatest in $S$. vesparium, and was lowest in $A$. clathrodes and $X$. rosariensis; $N$. amorpha was indistinguishable from the other species (Fig. 1).

The hole choice experiments showed that the 2 most abundant shrimp species in Spheciospongia vesparium could partition a size range of available spaces. Adult Synalpheus brooksi and Synalpheus longicarpus strongly preferred to occupy small $(5 \mathrm{~mm})$ and large ( $9 \mathrm{~mm}$ ) holes, respectively (Table 5). Considering only those shrimps that occupied a hole (i.e. excluding those

Table 5. Synalpheus brooksi, S. longicarpus. Results of laboratory choice experiments designed to test for partitioning of the size range of available spaces within a sponge. Two cooccuring Synalpheus spp. were offered a choice of artificial holes of different sizes. Small holes were $5 \mathrm{~mm}$ (S. brooksi) or $7 \mathrm{~mm}$ ( $S$. longicarpus) in diameter, large holes were $9 \mathrm{~mm}$ in diameter in both experiments. $\mathrm{p}$-values are from Chi-square (S. brooksi, $\mathrm{n}=17$ ) or binomial tests $(S$. longicarpus, $\mathrm{n}=14)$

\begin{tabular}{|lcc|}
\hline Hole choice & S. brooksi & S. longicarpus \\
\hline No. of replicates with shrimp in: & & \\
Small holes & 14 & 2 \\
Large holes & 2 & 12 \\
One of each & 1 & - \\
$\mathrm{p}$ & $<0.001$ & 0.006 \\
\hline
\end{tabular}

on the surface of the sponge piece), the number of replicates in which one or both Synalpheus brooksi were in small holes was significantly greater than the number in which shrimps occupied large holes or one of each size ( $p<0.001$, Chi-square with categories 'large' and 'each' combined). In contrast, Synalpheus longicarpus, which are larger, preferred to occupy large ( $9 \mathrm{~mm}$ ) over small ( $7 \mathrm{~mm}$ ) holes ( $\mathrm{p}=0.006$, binomial test), although they were physically able to occupy both.

\section{DISCUSSION}

\section{Host specificity of sponge-dwelling shrimps}

The evidence presented here indicates that many Synalpheus species are quite specific in their use of habitats or hosts. Of those species represented by more than 4 specimens in my collections, 8 of 12 species $(67 \%)$ in the gambarelloides group occurred primarily in sponges, and likely would have been found exclusively in sponges had rubble samples (which frequently contained encrusting sponges) been more carefully dissected. Thus these data confirm the impression from systematic studies (Dardeau 1984) that the gambarelloides group is primarily commensal. In contrast, 6 species of non-gambarelloides Synalpheus were found and none occurred regularly in sponges; this group apparently lives primarily in cavities within coral rubble. Within the commensal gambarelloides group, moreover, most species were associated with only a fraction of the available sponge species. For example, S. pectiniger (Table 1) (Dardeau 1984, Erdman \& Blake 1987) and S. agelas (Table 1) (Pequegnat \& Heard 1979, Dardeau 1984) each have been recorded reliably only from a single species (or 
genus) of sponge throughout their geographic ranges. $S$. bousfieldi was also found primarily in a single species of sponge in Panama (Table 1). Most of the other gambarelloides species were found in only 2 to 5 of the numerous sponge species present at the study site in San Blas. Thus while the entire host range of these species has not been documented, it is clear that they are rather specific in their host/habitat associations within a given site.

The reasons for such host specificity in commensal marine animals are almost entirely unknown. Association with sessile organisms in general is widely believed to provide guests with refuge from predators (Westinga \& Hoetjes 1981, Levinton 1982, Reed et al. 1982, Vermeij 1983), and experimental evidence supports this view for small invertebrates that associate with chemically defended seaweeds (Hay et al. 1989, 1990a, b) and for brittle stars that live in vase sponges (Hendier 1984). The reasons for association with particular host species are more elusive, however. Host size (Westinga \& Hoetjes 1981) and canal space dimensions (Fig. 1, Table 5) appear to determine the associated guest community to some extent. Host chemistry, distribution, competition with other guests, and differences among hosts in predation risk are all likely possibilities but there are few if any data available to evaluate most of them.

The specificity in host/habitat use by Caribbean Synalpheus species is all the more remarkable in light of apparently extensive regional variation in the species of sponges used as hosts. For example, $S$. bousfieldi, which is a characteristic inhabitant of Agelas species in the Gulf of Mexico, Bahamas, and Belize (Dardeau 1984, J. E. Duffy pers. obs.), was never found in collections of $A$. clathrodes in Panama although it was abundant in Niphates amorpha from the same reefs (Tables $1 \& 2$ ). Conversely $S$. brooksi, the only species regularly occupying $A$. clathrodes in Panama (Table 1), has not been found in Agelas spp. from the Gulf of Mexico, Bahamas (Dardeau 1984), or Belize (pers. obs.). S. goodei was the most abundant Synalpheus species in Spheciospongia vesparium from Curaçao (Westinga \& Hoetjes 1981), but was absent from this sponge in Panama (Table 1) despite being found in rubble nearby (Table 2). Interestingly, regional differences in host affiliations of several Synalpheus species studied by Dardeau (1984) were accompanied by considerable differences in the size of adult shrimps, and by more subtle differences in morphology, suggesting that these allopatric populations may compnse unrecognized cryptic species, which are common in alpheids and other crustaceans (Knowlton 1986). If so, then host specificity of synalpheids may be even narrower than presently recognized.

\section{Population consequences of the commensal lifestyle}

Living in sponges has several important consequences for shrimps, perhaps the most pervasive of which results from the architecture of the sponge canal system. Since occupied sponges showed no obvious signs of shrimp-induced canal enlargement, it appears that the size of available spaces limits the maximum size shrimps can attain, as it does for rubble-dwelling mantis shrimps (Steger 1987, Moran \& Reaka 1988). Among the 4 sponges studied here, both the mean size and size range of canal spaces differed (Fig. 1), and these differences were reflected in the differing body sizes of associated shrimp. This in itself is not surprising. However, space availability may mediate coexistence among Synalpheus species as well. Multiple species of Synalpheus occurred most regularly in Spheciospongia vesparium (Tables 1 \& 3), the host with the greatest diversity of canal widths (Fig. 1) Interestingly, the 2 most abundant species in this sponge overlapped very little in adult size (Fig. 1), and experiments showed that they preferentially use holes of different sizes (Table 5), supporting the hypothesis that adult shrimp partition the size range of spaces within their host. Likewise, structurally complex substrata or habitats tend to support more species of phytophagous insects (Strong et al. 1984), reefdwelling snails (Kohn 1967, Kohn \& Leviten 1976). invertebrates in seagrass beds (Heck \& Wetstone 1977), and marine decapod crustaceans generally (Abele 1974).

The host may influence guest populations not only through its intrinsic characteristics such as canal architecture, but also through its mediation of interactions between guests and their enemies (Price et al. 1980, Hay 1992). Although sponge-dwelling shrimps appear to be protected from generalist predators, which were rare or absent in sponge samples, sponge-dwelling apparently entails a greater exposure to parasitism (Fig. 2). The 4 species obligately ( $100 \%$ of individuals) associated with sponges averaged $15.7 \%$ infected with epicaridean isopods while the 4 species with $\leq 50 \%$ of individuals in sponges averaged $2.5 \%$ infected, a 6 -fold difference. These heavy parasite loads may well result from the high population densities that shrimps can achieve in sponges.

The constraints imposed by hosts on their guests are most readily seen by comparing conspecific populations in different hosts. In Panama, Synalpheus brooksi was common in Spheciospongia vesparium and Agelas clathrodes, and populations in the 2 host species differed demographically. Synalpheus brooksi reached smaller body sizes, and tended to produce fewer mature females, in A. clathrodes than in Spheciospongia vesparium (Table 4), probably as a conse- 
quence of the smaller average size of canal spaces in A. clathrodes (Fig. 1). Since Synalpheus brooksi was never found outside sponges, migration or age-specific habitat preferences seem less likely than host-induced effects to explain these demographic differences. Moreover, the diversity of potentially competing congeners was significantly greater in Spheciospongia vesparium (Table 3), and infection by branchial parasites was more than 3 times as high in populations of Synalpheus brooksi from $A$. clathrodes than in conspecifics from Spheciospongia vesparium (Table 4). Thus these 2 hosts appear to represent considerably different environments for Synalpheus brooksi.

\section{Evolutionary implications of commensalism}

The diversity of Synalpheus species in tropical waters is striking, with 24 species living sympatrically in the San Blas Islands. By comparison, the entire Caribbean is reported to support about 20 species in the amphipod genus Elasmopus (J. D. Thomas pers. comm.), 18 species in the reef-dwelling crab genus Mithrax (Rathbun 1925), 16 species in the stomatopod genus Squilla (Reaka \& Manning 1987), and about 13 species in the fiddler crab genus Uca (Crane 1975). The diversity of Caribbean Synalpheus species may derive in part from their small size (adults of many species are $\leq 2 \mathrm{~cm}$ in length) and cryptic lifestyle. In a variety of animal taxa, diversity is highest in lineages of species with relatively small (May 1986) though usually not the smallest (Dial \& Marzluff 1988) body sizes, probably as a result of higher speciation rates in smaller organisms (Dial \& Marzluff 1988). Among marine crustaceans specifically, Reaka \& Manning (1987) showed that both endemism and species richness within 'locally radiating clusters' of mantis shrimps were significantly greater in lineages with small body size.

Intimate association with other organisms may also contribute to high species richness in Synalpheus, as has been well documented in a variety of plant-feeding insects and parasites of animals (Price 1980, Mitter et al. 1988). The combination of host specificity (Table 1 , Fig. 4), restricted dispersal resulting from direct or abbreviated development of larvae (Dobkin 1965, 1969), the sedentary nature of adults, and their habit of mating within the host, are all likely to restrict gene flow among sponge-dwelling shrimp populations. Such fragmentation creates ideal conditions for local differentiation (Slatkin 1987), particularly when conspecific populations occupy different habitats, such as structurally and chemically diverse sponge species. Evidence that host-associated differentiation occurs in Synalpheus species is provided by the demographic differences between populations of $S$. brooksi in $A$. clathrodes and Spheciospongia vesparium (Table 4 , Fig. 1), together with significant divergence in allozyme frequencies among these same populations (Duffy unpubl.). Such divergence seems even more likely among the geographically separated populations of Synalpheus that use different hosts. Clearly the commensal lifestyle has pervasive consequences for the biology of these diverse shrimps.

Acknowledgements. This study would have been impossible without the assistance of my dive buddy, friend and colleague, Liz Canuel. I would also like to thank Fenner A. Chace Jr and Mike Dardeau for aid in identifying some of the more vexing Synalpheus specimens; Belinda Alvarez and Klaus Ruetzler for identifying the sponges; and in particular Nancy Knowlton and Brian Kensley for logistical support. advice and stimulating discussion. Insightful comments by Liz Canuel, Mark Hay, Nancy Knowlton, and several anonymous reviewers improved the manuscript. Support was provided by a Smithsonian Institution postdoctoral fellowship, a Smithsonian Tropical Research Institute short-term fellowship, a Sigma Xi grant-in-aid of research, a grant from the Lerner-Gray fund of the American Museum of Natural History, and NSF grant OCE 89-11872 to Mark Hay. I thank the Kuna nation and the government of Panama for permis. sion to work in San Blas.

\section{LITERATURE CITED}

Abele, L. G. (1974). Species diversity of decapod crustaceans in marine habitats. Ecology 55: 156-161

Banner, D. M., Banner, A. H. (1975). The alpheid shrimp of Australia. Part 2: the genus Synalpheus. Rec. Aust. Mus. 29: $267-389$

Chace, F. A. Jr (1972). The shrimps of the Smithsonian-Bredin Caribbean expedition with a summary of the West Indian shallow-water species (Crustacea: Decapoda: Natantia). Smiths. Contr. Zool. 98: 1-179

Chace, F. A. Jr (1989). The caridean shrimps (Crustacea Decapoda) of the Albatross Phillipine expedition, 1907-1910, Part 5: Family Alpheidae. Smiths. Contr. Zool. 46: 1-99

Coutière, H. (1909). The American species of snapping shrimps of the genus Synalpheus. Proc. U.S. natl. Mus. 36: 1-93

Crane, J. (1975). Fiddler crabs of the world. Ocypodidae: genus $U_{C a}$. Princeton University Press, Princeton

Dauer, D. M. (1973). Polychaete fauna associated with Gulf of Mexico sponges. Florida Sci. 36: 189-192

Dardeau, M. R. (1984). Synalpheus shrimps (Crustacea: Decapoda: Alpheidae). I. The Gambarelloides group, with a description of a new species. Memoirs Hourglass Cruises 7, Part 2: 1-125. Florida Dept Natural Resources, St. Petersburg

Day, R. W., Quinn, G. P. (1989). Comparisons of treatments after an analysis of variance in ecology. Ecol. Monogr. 59 $433-463$

Dial, K. P., Marzluff, J. M. (1988). Are the smallest organisms the most diverse? Ecology 69: 1620-1624

Dobkin, S. (1965). The first post-embryonic stage of Synalpheus brooksi Coutiere. Bull. mar. Sci. 15: 450-462

Dobkin, S. (1969). Abbreviated larval development in 
caridean shrimps and its significance in the artifical culture of these animals. FAO Fish. Rep. 57: 935-946

Erdman, R. B., Blake, N. J. (1987). Population dynamics of the sponge-dwelling alpheid Synalpheus longicarpus, with observations on $S$. brooksi and $S$. pectiniger, in shallowwater assemblages of the eastern Gulf of Mexico. J. crust. Biol. 7: 328-337

Hay, M. E. (1992). Seaweed chemical defenses: their role in the evolution of feeding specialization and in mediating complex interactions. In: Paul, V. J. (ed.) Ecological roles for marine secondary metabolites. Cornell University Press, Ithaca, p. 93-118

Hay, M. E., Duffy, J. E., Fenical, W. (1990a). Host-plant specialization decreases predation on a marine amphipod: an herbivore in plant's clothing. Ecology 71: 733-743

Hay, M. E., Duffy, J. E., Fenical, W., Gustafson, K. (1988) Chemical defense in the seaweed Dictyopteris delicatula: differential effects against reef fishes and amphipods. Mar. Ecol. Prog. Ser. 48: 185-192

Hay, M. E., Duffy, J. E., Paul, V. J., Renaud, P. E., Fenical, W (1990b). Specialist herbivores reduce their susceptibility to predation by feeding on the chemically defended seaweed Avrainvillea longicaulis. Limnol. Oceanogr. 35: $1734-1743$

Hay, M. E., Pawlik, J. R., Duffy, J. E., Fenical, W. (1989). Seaweed-herbivore-predator interactions: host-plant specialization reduces predation on small herbivores. Oecologia 81: 418-427

Heck, K. L., Wetstone, G. S. (1977). Habitat complexity and invertebrate species richness and abundance in tropical seagrass meadows. J. Biogeog. 4: 135-142

Hendler, G. (1984). The association of Ophiothrix lineata and Callyspongia vaginalis: a brittlestar-sponge cleaning symbiosis? P.S.Z.N. I: Mar. Ecol. 5: 9-27

Kaplan, E. H. (1982). A field guide to coral reefs of the Caribbean and Florida. Houghton Mifflin, Boston

Knowlton, N. (1980). Sexual selection and dimorphism in two demes of a symbiotic, pair-bonding snapping shrimp. Evolution 34: 161-173

Knowlton, N. (1986). Cryptic and sibling species among the decapod Crustacea. J. crust. Biol. 6: 356-363

Kohn, A. J. (1967). Environmental complexity and species diversity in the gastropod genus Conus on Indo-West Pacific reef platforms. Am. Nat. 101: 251-259

Kohn, A. J., Leviten, P. J. (1976). Effect of habitat complexity on population density and species richness in tropical intertidal predatory gastropod assemblages. Oecologia 25: 199-210

Levinton, J. S. (1982). Marine ecology. Prentice Hall, Englewood Cliffs

Lincoln, R. J., Boxshall, G. A., Clark, P. F (1982). A dictionary of ecology, evolution, and systematics. Cambridge Univ. Press, Cambridge

Markham, J. C. (1985). A review of the bopyrid isopods infesting caridean shrimps in the northwestern Atlantic Ocean, with special reference to those collected during the Hourglass cruises in the Gulf of Mexico. Memoirs Hourglass Cruises 7, Part 3: 1-155. Florida Dept Natural Resources, St. Petersburg

May, R. M. (1986). The search for pattern in the balance of nature: advances and retreats. Ecology 67: 11.15-1126

Mitter, C., Farrell, B. Wiegmann, B. (1988). The phylogenetic study of adaptive zones: has phytophagy promoted insect diversification? Am. Nat. 132: 107-128

Moran, D. P., Reaka, M. L. (1988). Bioerosion and availability of shelter for benthic reef organisms. Mar. Ecol. Prog. Ser. 44: 249-263

Moran, D. P., Reaka-Kudla, M. L. (1991). Effects of distur- bance: disruption and enhancement of coral reef cryptofaunal populations by hurricanes. Coral Reefs 9: 215-224

Nakashima, Y (1987). Reproductive strategies in a partially protandrous shrimp. Athanas kominatoensis (Decapoda: Alpheidae): sex change as the best of a bad situation for subordinates. J. Ethol. 5: 145-159

Pearse, A. S. (1932). Inhabitants of certain sponges at Dry Tortugas. Papers Tortugas Lab. Carnegie Inst. Washington 28: $119-122$

Pearse, A. S. (1950). Notes on the inhabitants of certain sponges at Bimini. Ecology 31: 149-151

Pequegnat, L. H., Heard, R. W. (1979). Synalpheus agelas, new species of snapping shrimp from the Gulf of Mexico and Bahama Islands (Decapoda: Caridea: Alpheidae). Bull. mar. Sci. 29: 110-116

Price, P. W. (1980). Evolutionary biology of parasites Princeton University Press, Princeton

Price, P. W., Bouton, C. E., Gross, P., McPheron, B. A., Thompson, J. N., Weiss, A. E. (1980). Interactions among three trophic levels: influence of plants on interactions between herbivores and natural enemies. A. Rev. Ecol. Syst. 11: 41-65

Rathbun, M. J. (1925) The spider crabs of America. U.S natl Mus. Bull. 129: 1-613

Reaka, M. L., Manning, R. B. (1987). The significance of body size, dispersal potential, and habitat for rates of morphological evolution in stomatopod Crustacea. Smiths. Contr. Zool. 448: 1-46

Reed, J K., Gore, R. H., Scotto, L. E., Wilson, K. A. (1982) Community composition, areal and trophic relationships of decapods associated with shallow- and deep-water Oculina varicosa coral reefs. Bull. mar. Sci. 32: 761-786

Robertson, D. R. (1987). Responses of two coral reef toadfishes to the demise of their primary prey, the sea urchin. Copeia 1987: $637-642$

Roughgarden, J. (1975). Evolution of marine symbiosis - a simple cost-benefit analysis. Ecology 56: 1201-1208

Slatkin, M. (1987). Gene flow and the geographic structure of natural populations. Science 236: 787-792

Snelgrove, P. V R., Lewis, J. B. (1989). Responses of a coralassociated crustacean community to eutrophication. Mar. Biol. 101. 249-257

Sokal, R. R., Rohlf, F. J, (1981). Biometry. Freeman, San Francisco

Steger, R. (1987). Effects of refuges and recruitment on gonodactylid stomatopods, a guild of mobile prey. Ecology 68: $1520-1533$

Strong, D. R., Lawton, J H. Southwood, R. (1984). Insects on plants. Harvard University Press, Cambridge

van Soest, R. W. M. (1980). Marine sponges from Curaçao and other Caribbean localities. Part II. Haplosclerida. Stud. Fauna Curaçao Caribb. Isl. 62(191): 1-173

Vermeij, G. (1983). Intimate associations and coevolution in the sea. In: Futuyma, D. J., Slatkin, M. (eds.) Coevolution. Sinauer, Sunderland, MA, p. 311-327

Westinga, E., Hoetjes, P. C. (1981). The intrasponge fauna of Spheriospongia vesparia (Porifera, Demospongiae) at Curaçao and Bonaire. Mar. Biol. 62: 139-150

Wiedenmayer, F. (1977). Shallow-water sponges of the western Bahamas. Birkhäuser, Basel

Zar, J H. (1974). Biostatistical analysis. Prentice-Hall, Englewood Cliffs

Zea, S. (1987). Esponjas del Caribe Colombiano. Catalogo Cientifico, Bogota

Zea, S., Ruetzler, K. (1983). A new species of Xestospongia (Porifera: Demospongea), from the Colombian Caribbean Caldasia 10: 817-831
This article was presented by K. L. Heck Jr, Dauphin Island Alabama, USA 